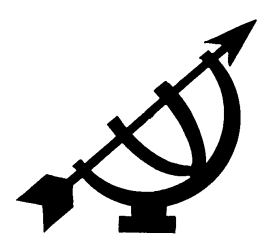

\title{
Why minds are changed: an inquiry into the decisions by the Gereformeerde Kerke in Suid-Afrika (GKSA) on the role of women in the church
}

\author{
H.J.M. (Hans) van Deventer \\ Subject Group Theology \\ School of Basic Sciences \\ Vaal Triangle Campus \\ North-West University \\ VANDERBIJLPARK
}

E-mail: bybhjmvd@puk.ac.za

For a long time, interpretation was taken for an activity that did not seem to require analysis of its own procedures (Iser, 2000:1).

Adherents of each doctrinal system constitute an "authoritative community" that dictates to the Bible that which the Bible is permitted to say (Noll, 2000:1).

\begin{abstract}
Why minds are changed: an inquiry into the decisions by the Gereformeerde Kerke in Suid-Afrika (GKSA) on the role of women in the church

Reading a text presupposes, at least to some extent, an attempt on the part of the reader to understand the text. This process is not always a smooth one, especially not when the text dates from a time and place very foreign to the reader. This article investigates one of the ways in which these "rough places", that inevitably limits the understanding of an ancient text, can to some extent be overcome. It takes as point of departure a modern-day contribution to literary theory. This is placed within the framework of a discussion in the GKSA with regard to the role of women in the church. It is suggested that the continuation of an interpretative tradition depends on the interaction between such a tradition and society.
\end{abstract}




\section{Opsomming}

\section{Waarom gedagtes verander: 'n ondersoek na die besluite van die Gereformeerde Kerke in Suid-Afrika (GKSA) oor die rol van vroue in die kerk}

Die lees van 'n teks impliseer ten minste in 'n sekere mate 'n poging aan die kant van die leser om die teks te verstaan. Hierdie proses verloop egter nie altyd glad nie, veral nie indien die teks dateer uit 'n tyd en plek wat baie vreemd vir'n leser is nie. Hierdie artikel ondersoek een van die maniere waarop hierdie "ongelyke terreine" wat die verstaan van 'n antieke teks inperk, tot 'n mate oorkom kan word. As vertrekpunt word 'n hedendaagse bydrae tot literêre teorie geneem. Dit word geplaas binne die raamwerk van 'n diskussie in die GKSA rakende die rol van vroue in die kerk. Daar word voorgestel dat die voortgang van 'n interpretasie-tradisie afhang van die interaksie tussen die tradisie en 'n samelewing.

\section{Introduction}

A lot has changed in South Africa over the past decade. The changes affect society at large - from the bastions of political power, through the field of economy, in academia, right down to the local school board. Most of these changes were the results of the democratisation of South Africa, following the 1994 general elections and the country subsequently taking its place in the international community. There were also other, seemingly unrelated changes that took place since 1994. This article focuses on one such change in a specific ecclesiastical community. During its 2003 national synod the Gereformeerde Kerke in Suid-Afrika (GKSA) decided to reverse an earlier decision related to the ordination of women in the church offices of deacon, elder and minister. In 2003 it was decided to allow women in the office of deacon. ${ }^{1}$

This article relates this change in polity to an understanding and interpretation of the Bible as religious text. The question posed here is: why did this change occur? This problem becomes a pressing one when it is noted that in this case there is a lot that did not change: surely the Bible, the text, stayed the same - it is the same

1 At the 2006 synod an appeal against this decision carried. This appeal was argued on basis of Church Order, articles 46 and 31 (GKSA, 2006:409-410) and did not present new hermeneutical material applicable to this study. This study was undertaken on basis of the 2003 decision and as such renders a contribution to the question of how communities understand religious texts. 
document read in the church for almost two millennia; also the Reformed tradition and its emphasis on divinely inspired authorship did not change. Informed by insights from the literary theorist Wolfgang Iser, this article investigates to what extent the reason for the change in interpretation could be related to that aspect in the communication process not mentioned thus far, namely the reader.

In arguing for a more reader-centred approach to biblical interpretation, this article starts with a historical survey of the issue pertaining to the role of women in the church (GKSA). This survey will focus mainly on official decisions taken on the subject by different synods, even though these decisions do not always indicate the general sentiment in the churches. This discussion will then be related to an existing hermeneutic in the GKSA. Lastly, the article considers what happens when texts, including the Bible, are read and interpreted. This will be done using a theoretical framework proposed by Iser.

\section{Historical survey of decisions related to the role of women in the GKSA}

The aim of this section is to provide a historical context for the decision that was taken by the national synod of the GKSA in January 2003, that paved the way for women to be elected and officially instated as deacons in the churches. Decisions by previous synods pertaining to this issue will be investigated and evaluated. A related issue on the right of women to vote for office bearers in the church, will also be noted. A concluding section will reflect on the prevalent hermeneutic underwritten by the GKSA and how it is reflected in the decisions discussed.

\subsection{How decisions are made - the church polity aspect}

By way of introduction, it is first of all necessary to look at a few aspects of church polity in the GKSA. The Presbyterial (Afr: presbiteriale) form of church government that is employed in the GKSA, implies that the local church council (in fact, the elders) is the most important governing body. Several local churches in the same geographical area come together in a classis (klassis) to deal with issues that cannot be resolved on the local church level. Such issues pertain to matters involving other churches in the area, such as financial assistance or solving an internal dispute in a local church. A number of classes in turn form a regional synod that deals with issues not resolved by a classis. In all instances the idea is not that of a hierarchical system where a classis or regional synod is 
viewed as a higher authority than respectively a local church council or a classis. Instead of a vertical increase in authority, there is a horizontal increase in representation from the churches. In matters that have bearing on the function of all the churches adhering to the common accord, such as matters related to liturgy and hymns, regional synods appoint elders and ministers to meet every three years in order to deal with these, at a national synod. This meeting also deals with complaints and appeals from any of the other church council, classis or regional synod meetings regarding decisions that are not viewed to be in line with the common accord among the churches (Spoelstra, 1989:17, 177-202).

\subsection{Decisions that were made - the role of women in the GKSA2 $^{2}$}

\subsubsection{The first question: to vote or not to vote?}

It was fifty-nine years after the establishment of the GKSA in 1859 that the issue of women voting for (male) office bearers landed on the table of the 1918 synod (GKSA, 1918; art. 143). A discussion point (beskrywingspunt) was tabled, calling for a statement regarding women's right to vote in the church. The decision recorded by the minutes of that meeting merely mentions that women do not have voting rights in the church. This was in line with the general state of affairs, since women, at that time, also did not have political franchise. In that regard, another discussion point called on the synod to make a statement regarding women's right to vote for political leaders (GKSA, 1918; art. 144). The synod decided to refer this matter to a commission for reporting at a later meeting. 3 This report was treated by the next synod in 1920 (GKSA, 1920; art. 72 , along with appendix $\mathrm{H}$ ). The report stated that the calling of women was especially related to family life. However, where women were forced to be the breadwinners, for example in the area of social service, they could be of immense help in the "school, hospital

2 This section is partly based on an unpublished paper initially presented by the author to a closed group of concerned members of the GKSA in Sasolburg in 2001. Subsequently it formed part of a larger document presented by this group to the study commission appointed by the 2000 synod. As part of that document it has been referred to by other scholars (cf. Pieterse, 2002).

3 This procedure stayed the same over time. After a commission of the synod had studied an assigned topic, it reported back at the next synod. During this next synod another (internal) commission is appointed to deal with this report in detail and then to advise the synod on a decision to be taken. 
and Red Cross" (translation - HJMvD). In the political arena women's franchise should be opposed. The synod also decided to publish a brochure to this effect.

For the next thirty years, not much in respect of the position of women in the GKSA was heard. However, in 1952, the synod (GKSA, 1952; art. 259) decided to appoint delegates to the Reformed Ecumenical Synod (RES) that was to be held in Edinburgh the following year. The report of the delegates to the RES was tabled at the 1955 synod (GKSA, 1955:229; art. 175). It was reported that one of the issues discussed by the RES, related to advice sought by the Christian Reformed Church in the USA regarding the right of women to vote at meetings of the congregation. The commission appointed by the RES to consider this matter, reported in 1953 that there are no Scriptural grounds on which women can be prohibited to vote. Thus, the RES accepted a recommendation from their commission to sanction franchise for women in the church. At the 1955 GKSA synod meeting, it was reported that the delegation of the GKSA proposed, that the matter should be referred back to the churches for further study, but that the RES rejected this proposal. The delegation of the GKSA proposed to the 1955 synod, that a commission be appointed to study the report and decisions of the RES and to report back to the following GKSA synod in 1958. The 1955 synod accepted this proposal. In an unprecedented move within the context of Reformed church polity, it was asked that a number of votes against the appointment of such a commission should be recorded in the minutes. Was this perhaps an indication of unease among some delegates to change the status quo?

The commission appointed in 1955 by the GKSA to study the report and decisions of the RES (1953), reported (GKSA, 1958:289; art. $110)$ back at the synod meeting of 1958. They indicated that the RES accepted the recommendation regarding franchise for women in the church on basis of the equality of man and woman in Christ. The commission was, however, of the opinion that this principle should not only apply to the right of women to vote, but also to women's eligibility to be elected into the offices of the church. Furthermore, the commission asked whether the right to vote was not a form of governance (gesagsuitoefening) and therefore in conflict with God's "ordained state" for women. The commission also asked whether women's political franchise was not perhaps determining what should happen in the church, whereas in the past it used to be the other way around. Taking this report as a point of departure, the 1958 synod decided that, on the grounds that the 
right of women to vote in the church implies their right to be elected in the offices, the GKSA synod will not accept the report of the RES (1953) regarding the right of women to vote in church. 4

\subsubsection{The second question: to be or not to be office bearers?}

One again, a 15-year period of silence on this issue follows. In 1973 the GKSA synod (GKSA, 1973:119; art. 76) decided, on basis of a report on the offices in the church that served at the RES meeting in Sydney (1972), to appoint a commission to study the matter of women in the office of deacon. However, the synod failed to appoint any members for this commission (!). It is only in 1979, after advice sought by the Northern Transvaal regional synod, regarding the place of women in the church, and two discussion points regarding women in the office of deacon, that the synod decided to appoint a commission to study the role and place of women in the church, with regard to offices, service and voting. This study was to be conducted in the light of the Scriptures, Confession and Church Order (GKSA, 1979:563-565; art. 163-165).

The 1979 synod also had to deal with an objection (beswaar) from the Boland classis to previous decisions (1920; 1958) regarding franchise for women (GKSA, 1979:317-325; art. 92). This objection listed, among others, the synod's one-sided references to the Scriptures, in making these decisions. It argues against the synod's decisions on this matter, by citing other references to Scripture that view women as part of the congregation and as such as equal members (mondige lidmate) (GKSA, 1979:319). The commission that the synod appointed to deal with this objection, reported that the objection was not founded on good exegesis (GKSA, 1979:323) and the synod consequently decided not to uphold the objection. The report of this internal commission contained, however, a few noteworthy statements. It mentioned that, regarding the right of women to vote in the church, the synod had not yet taken any decision (GKSA, 1979:322), thereby ignoring the decision of 1918. Furthermore, this internal commission stated that the right to vote was an act of governance and, as such, not appropriate for women in the church. The report of the internal commission gives the impression of hiding behind technicalities, in order not to address the essence of the objection.

4 The carefully-formulated Afrikaans states: "om die besluit 'nie vir sy rekening te neem nie"'. 
In 1982 the synod (GKSA, 1982:501; art. 130-131) found the report, tabled by the commission appointed in 1979, to exhibit a lack of conclusions and recommendations. The report also showed signs of ambiguities and, therefore yet another commission, charged with the same task as the previous one, was appointed to investigate these issues and problem areas. The report of this commission to the synod in 1985, was deemed to have inherent deficiencies of a preliminary nature and consequently the synod decided (GKSA, 1985:325; art. 82) to withhold pronouncement on the content and recommendations of the report, and again appointed a commission with the same task. It is significant that the tabled report stated that, with regard to the office of deacon, Scriptural evidence on the whole indicated the eligibility of women to be called to this office.

In 1988 an extensive report of the commission dealing with "the place of women in the church" was tabled and addressed both the issue of women's right to vote for office bearers and the issue of women serving in the offices (GKSA, 1988: 502; art. 97). With regard to voting, it was decided that, due to the fact that women were full members of the body of Christ and thus of the congregation, they may participate in the election of male office bearers. This decision was based on a simple syllogism:

- The congregation elects officials (Church Order, art. 22 as amended by the synod of 1964).

- Women are full members of the congregation.

- Thus, women may (should) elect officials.

This decision was not based on material from the Bible, creeds and church order that already served at previous synods, especially as objections to previous decisions. Instead, it was based on the issue of equality that synods previously did not want to uphold.

With regard to the issue of "the place of women in the church" the report of the study commission (cf. GKSA, 1988:507; art. 98) came to the conclusion that, in exceptional circumstances, women can be gifted and called by God to render a specific service. However, the synod decided that, due to the fact that no definite and conclusive Scriptural grounds were cited, the report, as a whole, was not acceptable. 5 deacon, followed a similar route: the internal commission of the synod dealing 
In 1994 an appeal against the 1988 decision on women in the offices, was tabled (GKSA, 1994:467; art. 74). The synod decided, on recommendation of its internally appointed commission, that this appeal could not be successful. The reasoning of the internal commission deserves comment. The appeal stated and reasoned that the synod underestimated the role of women in the New Testament. The internal commission then referred to the full study report tabled in 1988 to refute this statement. However, the commission did not take into account that the recommendations flowing forth from this 1988 report were not accepted by synod. It is exactly this non-acceptance that led to the 1994 appeal!

In 1997 another appeal against the 1988 decision, regarding electing women in the offices, was lodged (GKSA, 1997:546; art. 33). It stated that the 1988 decision was premature and that the synod did not interpret Scripture in a responsible manner. Due to time constraints, the synod decided to appoint another commission to test the exegesis of the appellants and to advise the following synod regarding their appeal. It should be noted, that the synod requested more time to study this appeal, but that in 1988 a much more comprehensive report was not tested on exegetical grounds. The recommendations regarding the election of women to the offices were rejected, without applying any further exegetical testing. Also, in 1997, the synod decided to approve a request from the Northern Transvaal regional synod to contact churches abroad, regarding their positions on allowing women into the offices, in order to determine how differences in this regard influence the unity of the churches.

In 2000 the commission that studied the exegesis of the 1997 appeal reported back (GKSA, 2000:157-164; 15.2 of agenda), and concluded that the grounds of appeal were not sufficiently proven. The internal commission that had to advise the synod on this report, recommended that the report should be approved, a recommendation that the synod followed. After this decision, it seems as though the case regarding opening the offices in the GKSA to women, had finally been closed. However, the synod decided to appoint a commission to study "what the Bible reveals about the manner in which the Lord used and still uses women in his church". This decision followed on a discussion point put forward by

with the appeal, recommended that the appeal against the 2003 decision should not carry; however, the synod rejected this recommendation and thus recalled the 2003 decision. 
the Western Transvaal regional synod. At first it seemed that, in the light of all the decisions already taken by the synod regarding the offices, this commission could not deal with that issue again. In the end, this presumption proved to be wrong, and the whole issue of the offices landed on the table of the 2003 synod - again. Before turning to that synod, another discussion point adhered to at the 2000 synod deserves attention.

\subsubsection{The third question: what if all of us do not do the same?}

Taking its cue from the 1997 decision with regard to contacting churches abroad, another discussion point from the Northern Transvaal regional synod was passed. It decided to appoint a commission to investigate whether the differences, regarding admission of women to the offices, found in the GKSA on the one hand, and the Reformed Church in the Netherlands (GKN) and the Christian Reformed Church (CRC) in the USA on the other hand, was the result of differing and critical views of Scripture, in which case the unity with the GKSA is threatened.

This lays bare a core problem in the GKSA, namely a tendency to view any varying interpretation of Scripture with suspicion and classifying it under the unnerving "critical view of Scripture" label. Often such a point of view reflects an insufficient insight into the process of text production, general hermeneutics, the dynamics of interpretation and related issues. Furthermore, no definition of "a critical view of Scripture" is ever given. In an academic context, it is common knowledge that any interpretation of any text builds on a critical theory. In church circles, this insight seems to be lacking, despite the long study period at university level, which is prescribed before a man (!) may enter the ministry. When the report of this commission, dealing with a suspected "critical view of Scripture" by denominations in the USA and the Netherlands, was tabled in 2003, it merely stated that discussions in this regard will continue (GKSA, 2003:184, 185; art. 2.3.3, 2.3.10). To the 2006 synod it was reported that, with regard to the $\mathrm{CRC}$, a critical approach to Scripture (Skrifkritiese benadering) could not be found (GKSA, 2006:204; art. 1.8.3.2), and with regard to the $G K N$, it was decided that the discussion about the view of Scripture and hermeneutics should continue (GKSA, 2006:197; art. 1.2.3.4). 


\subsubsection{The second question, again: to be or not to be office bearers?}

In 2003 the GKSA implicitly decided to reverse its decision on the issue of women in the offices, when it decided to open a door for women to serve in the office of deacon (cf. GKSA, 2003:591, 593). This decision is said to be implicit, as it is not possible to locate the exact article where a decision to this effect is recorded in the official, bounded minutes of the 2003 synod. It is only when read in conjunction with a single page, "Errata", that the Administrative Bureau of the GKSA distributed separately, that the decision becomes apparent in the document referred to above. What makes this decision remarkable, is the fact that in essence no other evidence or conclusions were rendered to clarify the matter; 6 exactly the same recommendations proposed by the 1988 commission and rejected by the 1988 synod, were put on the table.

\subsection{How decisions are made - the hermeneutical aspect}

From the preceding historical account, it ought to be clear that a core problem in the GKSA is a hermeneutical one. This concluding section briefly elaborates on the issue. It was noted that suspicion arose in the GKSA when an interpretation of Scripture, that differs from a traditionally held view, was put forward; a point aptly illustrated by Kruger (1993:590). Ironically, it should be a trademark of the reformed tradition with its emphasis on the office of the mature believer, and not on the authoritative church tradition, that new interpretations arise from time to time (Barton, 1998:16). In the GKSA serious reflection on the hermeneutical process was largely lacking in the 20th century. It was only in 1980 that an article dealing with hermeneutics was published (Coetzee et al., 1980:18-36). On basis of an acknowledged narrow definition of hermeneutics (Coetzee et al., 1980:18), this article does not take into consideration any of the developments in the field of general hermeneutics that had an impact on the theory of understanding, since the middle of the 20th century. Although there have been attempts to point out or address this insufficiency (cf. Botha, 1986; Snyman, 1992a; 1992b; Kruger, 1993; Deist, 1994), no serious effort in this regard was undertaken (cf. however, a response by Vergeer, 1993 and a suggestion by Van Deventer, 1996). The 1980 article still seems to form the basis for hermeneutical reflection in the

6 A list of unresolved issues was referred to another commission (GKSA, 2003:593; art. 14.1-14.8). 
GKSA, as is seen in its citation by Jordaan and Du Plessis in an appeal brought before the 2006 synod (GKSA, 2006:543).

However, there are indications that at least some critics and writers realise the complexity of the interpretation process. In an introductory work dealing with the compilation of a sermon, Janse van Rensburg and De Klerk (2005) mention that interpretation is "fallible work", done tentatively and allow for checkpoints for valid exegesis (2005:6-9). As this is a practical manual, aimed at students creating sermons, very little theoretical reflection is provided, however, a close reading of their principle point of departure reveals familiarity with Hirsch's distinction between meaning and significance. In evangelical circles, Hirsch's ideas were popularised by Kaiser and Silva (1994:30-31, 41-44) in an introductory work dealing with biblical hermeneutics. Although this source is profoundly evangelical in outlook, these authors realised the connectedness between understanding the Bible and understanding any other text. They recognise that the eight levels of meaning they distinguish in a biblical text "are relevant for the interpretation of anything" (Kaiser \& Silva, 1994:20-23). Thus they add four further principles on top of these levels of meaning, that distinguishes biblical hermeneutics from general hermeneutics (Kaiser \& Silva, 1994:23-25). Their important insight is that biblical hermeneutics cannot be severed from general hermeneutics.

The rest of this article investigates how a modern theory related to general hermeneutics, also helps in providing a possible reason for a change of heart, regarding the role of women in the church as reflected in synod decisions in the GKSA up to 2003.

\section{Interpreting an ancient religious text: a modern perspective}

What became clear in the preceding discussion, is that a religious text, such as the Bible, does not render a clear-cut answer to a modern problem, in this case, to the role of women in the church and in society. ${ }^{7}$ There are mainly two reasons for this:

7 Armstrong (2000:337) in fact links such a view of sacred literature as a manual for immediate practical action instead of a source of personal inspiration and moral guidance to fundamentalist strands in religion (see also Ruthven, 2004:87-91 for an elaboration on this idea). A more balanced view is put forward by Heinemann (1986:49) who views guiding and strengthening of faith as resulting from the primary aim of (midrashic) interpretation, namely to "take a stand on the burning issues of the day". 
- Biblical texts were mostly, if not exclusively, written by men living in a patriarchal society, and therefore women do not feature prominently in these texts, especially not outside the patriarchal frame of reference (cf. Trible, 1982:3); and

- the biblical texts were compiled during an age when gender issues were not the burning issues of the day. This also holds true for a long period in Western history. Even 150 years ago gender issues were by and large non-issues in society. J.S. Mill's work published in 1869 is the first major attempt at addressing the plight of women in society (cf. Mill, 1996 [1869]).

For faith communities functioning in the 21st century, however, things have changed. Women currently constitute a large part of the work force in almost all sectors of life. In present day religious communities, women rightly feel that they can contribute in ways other than those men, who hold positions of power, traditionally prescribed for them. The discussion above hints, that changing contexts could perhaps lead to different understandings of the Bible. In this following section a theoretical framework for testing such a notion is put forward. Since we are dealing with the understanding of a written text, the theory comes from the realm of literary criticism.

\subsection{How to fill a blank (Iser)}

The theory to be considered here was developed by Wolfgang Iser, a representative of the so-called Konstanz school. Aligning a theory related to fictional literary works, with a modern-day understanding of an ancient religious text such as the Bible, is not a straight forward procedure.8 There are those who deny the validity of such a proposal (cf. Pellegrini, 2000:56), ${ }^{9}$ especially since Iser (1978:7-8) rejects the literary critic's search for a single referential meaning in a text. The aspects of Iser's theory that are used here are, however, general enough to be applied as a heuristic tool. Furthermore, the focus of the present article is not on understanding the biblical text, but on understanding a reading community's understanding and interpretation of the text.10 Iser (1978:21) states that the "work itself"

8 Thiselton (1992:518-522), however, provides a number of examples of biblical scholars utilising Iser's insights.

$9 \quad$ This is contra-Thiselton (1992:516), who views Iser's theory as "moderate" and one that "has stimulated some creative reflection in biblical studies."

10 This places the discussion squarely in the hermeneutics tradition as introduced by Schleiermacher (cf. Iser, 2000:41-55). 
is virtual in character "as it cannot be reduced to the reality of the text or to the subjectivity of the reader". It is from this virtuality that the work derives its dynamism and that meaning ceases to be a definable entity, but becomes a dynamic happening (Iser, 1978:22). Applied to an ancient religious text, this means that the different interpretations of the Bible by different faith communities, underscore this dynamism. Iser (1978:23-24) goes on to indicate how even in a single-meaning theory there exists, what he calls "sophisticated subjectivity" based on (unacknowledged) external frames of reference. Thus, a reader-orientated approach is by no means more subjective than traditional "objectivist" approaches. In fact, the structure of the text does allow for some form of control by the text over the (implied) reader (Iser, 1978:24, 34). The fact that we are drawn into a text, is the result of indeterminacies in the text, experienced as an imbalance between text and reader, that the reader needs to bridge (Iser, 1978:167, 168).

Iser (1978:181) defines a literary work as a structure of communication that is neither identical to the real world, nor to the disposition of its readers. In this ambivalence lies its potential to communicate. There are, apart from the formulated determinatives in a text, also indeterminacies "which relate less to the text itself, than to the connections established between text and reader during the reading process" (Iser, 1978:182). These indeterminacies, or blanks, in the written text "indicate that the different segments of the text are to be connected" by the reader (Iser, 1978:183). In a written text the "good continuation" a reader expects, is annulled by the principle of economy. Iser (1978:186) goes on to explain that "[a]s a result, the imagination is automatically mobilized, thus increasing the constitutive activity of the reader, who cannot but try and supply the missing links that will bring the schemata together in an integrated gestalt".

Iser refined these ideas in his later work, broadening the range of interpretation beyond the interpretation of written texts (Iser, 2000:68). His discussion of textual interpretation also saw newer insights added. In a section dealing with canonised texts, Iser (2000:20) states that over and above the indeterminacies in the text, the process of canonisation introduced a further "liminal space" between the canon and its interpretation. The very act of canonisation necessitated subsequent acts of interpretation, in an attempt to bridge the gap between the canon and the life of the people: "[i]nterpretation highlights the fact that canon and community do not coincide, and that although it created this split in the first place, it also strives to overcome it" (Iser, 2000:16). 
When viewing the significant change in polity regarding the role of women in the GKSA against the background of Iser's insights, it points only in one direction, namely that the reader is actively taking part in the interpretive process (cf. Thiselton, 1992:515). The reader cannot be seen as a mere passive "receiver" of information provided by the text. The reader is active in the process of creating meaning. ${ }^{11}$ An immediate concern would be where the reader gets the material from, in order to bridge the gaps in the text and those between the text and present-day societies. On this point Iser puts forward two closely related submissions. The first of these relates to "projections" produced by the reader (Iser, 1978:167). These projections will differ from reader to reader and are informed by readers' different "historical or individual circumstances" and "will be colored by the reader's existing stock of experience" (Iser, 1978:37, 38 ), also referred to as "our existing store of knowledge" (Iser, 1978:177). The idea is not, however, that of a blind subjectivity Iser very specifically steers away from this (Iser, 1978:23).12 Therefore, the second submission is that it is the text that, in the first place, "sets off a sequence of mental images" in the reader (Iser, 1978:38). The "constitutive activity" of the reader is structured by the blanks in the text and in this way it "controls the process of interaction" (Iser, 1978:170).13 Iser (1978:189) further elaborates on how, during the reading process, a reader continuously needs to adjust the "first degree" images she/he created in favour of "second degree" images, as she/he passes through the text (cf. Selden 1989:120), and is thus steered by the text. Iser (1978:190) indicates how in different types of texts, the process of bridging the blanks can be dictated to some extent by the author. In a "thesis novel" for instance, the intention is didactic, therefore the readers' participation "must be strictly controlled and that is why the scope [of choice for the reader] must be minimal".

11 This simple fact can even be seen in a reading community, such as a Bible study group, where the different members create different meanings when reading the same text. The same holds true for the fact that new commentaries on Bible books continue to appear.

12 In fact, Fish (1989:68-86), who in his later work transfers the whole interpretative project to the realm of the reader, even to the extent that everything becomes interpretation without any fixed point of meaning, is very severe in his criticism of Iser, due to the latter's middle-of-the-road stance in which the text is given a (regulatory) part in the process of meaning formation.

13 In his very readable dealing with the problem of pluralism, albeit a little dated, Booth (1979:241) refers to 'boundaries of 'appropriateness' [that] are set by the text as it moves in us". 
If one takes Iser's insights regarding what happens during the interpretative process into account, it should be clear that any objectivist idea about a fixed and final textual meaning cannot be upheld. The whole history of interpretation cries out against such a view. Within a religious community and regarding a sacred text, this acknowledgement will at first sound quite alarming. However, this notion of reader involvement in meaning creation is not an idea thought out by twentieth century theorists. Iser merely describes what indeed happens in the process of interpretation. The decisions by the GKSA regarding the role of women in the church, seem to bear out this description. Furthermore, this phenomenon did not first appear in modern reading communities and is therefore not only to be noted in recent times. The next section briefly looks at a scholarly investigation of the same process of meaning production as revealed by the biblical text itself.

\subsection{How a blank was filled: a case study - Snyman on Chronicles}

In his doctoral thesis Snyman (1991) argues, on basis of the story of the Ark of the Covenant represented in both Samuel-Kings and Chronicles, that the biblical text itself testifies to the reader's involvement in the production of meaning. Snyman (1991:194-196) bases his work on the theory of another exponent of the Konstanz school, namely Hans Robert Jauss. Jauss emphasises Rezeptionsgeschichte, or history of the text's reception by different historical communities. Snyman (1991:159-163) argues that the author of Chronicles transforms the sacred story of the ark (2 Samuel 6). In Chronicles this story is told in a different way in order to address the problems related to the post-exilic community. ${ }^{14}$ In this regard the words of Eagleton (1983:12), related to reader-response, are applicable: "All literary works [...] are 're-written', if only unconsciously so, by the societies which read them; indeed there is no reading of a work which is not also a 're-writing."'

Thus, we have seen that the role of the reader as an active participant in the reading process, even to the extent of changing a sacred story, is attested in the biblical text. In the case of the ark story, the blanks in the original story are filled and adapted in such a direction where a solution could be found" (Snyman, 1991:298). 
way as to address the needs of a post-exilic community. One can say that a past situation influenced the way the story was re-read and adapted by a later audience for the needs of their specific time. 15

In the case of the post-exilic community for whom the story of the ark had been adapted, we can form some idea of the issues with which this community was grappling. ${ }^{16}$ What has been preserved in the text of Chronicles is an attempt, from a specific point of view, to address these issues. We only have textual testimony to the way in which certain (influential) people filled the blanks in the original story. They filled the blanks from a specific stance: their post-exilic situation. One can say that a past societal concern influenced their re-reading of the ark story. ${ }^{17}$ We can extrapolate these circumstances from the new text that emerged.

From what has been said thus far, two things became clear: 1) readers are active in the process of interpretation; and 2) the activity can be informed from at least two vantage points: one related to the text (and perhaps its past understanding[s]); and one related to (the needs of) a present reading community (present understanding). Lastly, we should consider what happens when past and present meet.

\section{When past meets present}

It is already noted that the activity of the reader in the interpretation process is informed by, what Iser (1978:37) refers to as his/her "historical circumstances". The debate about the role of women in the church underscores this notion: it was only after the roles of women in society at large changed, that the same happened in the church. Still, since this change of mind had to be informed by the

15 Although not always recognised in strongly dogmatic-orientated reading communities, the texts of the Old Testament exhibit a certain plurality. Thus Knierim (1984:25) can begin his discussion of the task of Old Testament theology by remarking the following: "The Old Testament contains a plurality of theologies. This fact is well established exegetically." It is this problem that Old Testament theology addresses.

16 Albertz (1992:544-556) gives an overview of these issues.

17 A similar conclusion is reached by Kasher (2001) after a discussion of the three reports on the illness of Hezekiah. He states that the account of this story in Chronicles testifies "to the tendency of the Biblical authors to edit existing material in accordance with their own needs". 
sacred text, a long period of study in this regard ensued. The gaps in the text hold the promise of always producing newer meanings, as readers in different circumstances seek to understand the text. There is also a larger gain from the reader's participation in the process of understanding.

Lieven Boeve, a philosopher of religion, argues that something similar happens within broader entities such as religious belief systems. He is in search of an epistemological basis for "doing theology" in a postmodern context. After a brief overview of a few postmodern voices, Boeve (1996a:213-220) concludes that the influence of postmodernism on our reading of Scripture lies to a large extent in a protest against authoritative structures, that hinder the biblical message proclaiming freedom (in its various forms) to be actualised within the specific community's existential context of their day to day existence (cf. Postmodern Bible, 1995:11-12). This context is very often far removed from the context of the authoritative interpreting community. These forms of protest are built on different existential contexts and therefore interpretations will also differ.

Boeve's main concern is not biblical interpretation, but the continuation of the Christian tradition, that is one among many, within the pluralistic postmodern condition. Within a postmodern society, with all its radical subjectivity, Boeve still sees a place for tradition. However its role is not to repeat the truth; instead, it plays a role in our search for truth (Boeve, 1996b:70). Tradition is not the source for the absolute truth, but the basis for dialogue with a postmodern context. In this dialogue an adapted, but living tradition is born that in turn becomes the legacy of a present society and is picked up and again adapted by a next generation. I believe what Boeve says about the broader Christian tradition also holds true for interpreting the Bible.

This means that far from eroding tradition by accepting newer readings of the text, as informed according to Iser by the text itself, the "happening" of interpretation which undisputedly carries with it the participation of the reader, in fact translates a tradition into a present context and thus guarantees its further continuation.

\section{Summarising thoughts}

In the tradition of Reformed Philosophy it has been realised since its inception, that a value-free objectivist form of science is not attainable, and that there is an element of subjectivity inherent to the 
process - albeit implicit. Applied to the field of hermeneutics (the science of understanding) it means that the reader is involved in the process of creating meaning. In the latter part of the twentieth century literary theorists, such as Iser and others, suggested theoretical frameworks to account for this fact. In the same manner that Iser (1978:13) recognises the literary work to be larger than the text,18 reading communities of the Bible should recognise that the Word is immensely larger than the biblical text (Kruger, 1993:593). The change of mind within a specific religious community, with as regard to the role of women in the church, seems to provide a good example of this phenomenon related here to the understanding of a sacred religious text.

\section{List of references}

ALBERTZ, R. 1992. A history of Israelite religion in the Old Testament period. Vol. 2. Louisville: Westminster/John Knox.

ARMSTRONG, K. 2000. The battle for God: fundamentalism in Judaism, Christianity and Islam. London: HarperCollins.

BARTON, J. 1998. Historical critical approaches. (In Barton, J., ed. The Cambridge companion to biblical interpretation. Cambridge: Cambridge University Press. p. 9-20.)

BIBLE AND CULTURE COLLECTIVE. 1995. The postmodern Bible. New Haven: Yale.

BOEVE, L. 1996a. Een postmoderne theologie van het 'open verhaal'. Onze Alma Mater, 50(2):210-238.

BOEVE, L. 1996b. Erfgenaam en erflater: kerkelijke tradities binnen de traditie. (In Lombaerts, H. \& Boeve, L., reds. Traditie en initiatie: perpectieven voor de toekomst. Leuven: Acer. p. 43-77.)

BOOTH, W.C. 1979. Critical understanding: the powers and limits of pluralism. Chicago: University of Chicago Press.

BOTHA, J. 1986. Die gereformeerde Skrifbeskouing en moderne metodes van verklaring van die Nuwe Testament. Koers, 51(3):259-286.

COETZEE, J.C., DE KLERK, B.J. \& FLOOR, L. 1980. Die hermeneuse van die Skrif met die oog op hedendaagse kerklik-etiese vraagstukke. Koers, 45(1):18-36.

DEIST, F.E. 1994. Onlangse konsepte in teksuitleg en hulle konsekwensies vir die (gereformeerde) teologie. In die Skriflig, 28(2):165-178.

EAGLETON, T. 1983. Literary theory: an introduction. Oxford: Blackwell.

FISH, S. 1989. Doing what comes naturally: change, rhetoric and the practice of theory in literary and legal studies. Oxford: Clarendon.

GKSA. 1918. Handelinge van die 19e algemene sinodale vergadering van die Gereformeerde gemeentes in Suid-Afrika. Bloemfontein: Nationale Pers.

GKSA. 1920. Handelinge van die 20e algemene sinodale vergadering van die Gereformeerde gemeentes in Suid-Afrika. Bloemfontein: Nationale Pers. 
GKSA. 1952. Handelinge van die 31e sinodale vergadering van die Gereformeerde gemeentes in Suid-Afrika. Potchefstroom: GKSA.

GKSA. 1955. Handelinge van die $32 e$ sinodale vergadering van die Gereformeerde Kerk in Suid-Afrika. Potchefstroom: GKSA.

GKSA. 1958. Handelinge van die $33 \mathrm{e}$ sinodale vergadering van die Gereformeerde Kerk in Suid-Afrika. Potchefstroom: GKSA.

GKSA. 1973. Handelinge van die $38 \mathrm{e}$ sinodale vergadering van die Gereformeerde Kerk in Suid-Afrika. Potchefstroom: GKSA.

GKSA. 1979. Handelinge van die 40e sinodale vergadering van die Gereformeerde Kerk in Suid-Afrika. Potchefstroom: GKSA.

GKSA. 1982. Handelinge van die 41e sinodale vergadering van die Gereformeerde Kerk in Suid-Afrika. Potchefstroom: GKSA.

GKSA. 1985. Handelinge van die 42e sinodale vergadering van die Gereformeerde Kerk in Suid-Afrika. Potchefstroom: GKSA.

GKSA. 1988. Handelinge van die 43e nasionale sinode van die Gereformeerde Kerke in Suid-Afrika. Potchefstroom: GKSA.

GKSA. 1994. Handelinge van die 45e nasionale sinode van die Gereformeerde Kerke in Suid-Afrika. Potchefstroom: GKSA.

GKSA. 1997. Handelinge van die 46e nasionale sinode van die Gereformeerde Kerke in Suid-Afrika. Potchefstroom: GKSA.

GKSA. 2000. Handelinge van die 47e nasionale sinode van die Gereformeerde Kerke in Suid-Afrika. Potchefstroom: GKSA.

GKSA. 2003. Handelinge van die 48e nasionale sinode van die Gereformeerde Kerke in Suid-Afrika. Potchefstroom: GKSA.

GKSA. 2006. Handelinge van die 49e nasionale sinode van die Gereformeerde Kerke in Suid-Afrika. Potchefstroom: GKSA.

HEINEMANN, J. 1986. The nature of the Aggadah. (In Hartman, G. \& Budick, S., eds. Midrash and literature. New Haven: Yale University Press. p. 4155.)

ISER, W. 1978. The act of reading: a theory of aesthetic response. London: Routledge \& Paul.

ISER, W. 2000. The range of interpretation. New York: Columbia University Press.

JANSE VAN RENSBURG, F. \& DE KLERK, B.J. 2005. Making a sermon: a guide for reformed exegesis and preaching. Potchefstroom: Potchefstroomse Teologiese Publikasies.

KAISER, W.C. \& SILVA, M. 1994. An introduction to biblical hermeneutics. Grand Rapids: Eerdmans.

KASHER, R. 2001. The Sitz im Buch of the story of Hezekiah's illness and cure (II Reg. 20,1- 11; Isa. 38,1-22). Zeitschrift für Alttestamentliche Wissenschaft, 113:41-55.

KNIERIM, R. 1984. The task of Old Testament theology. Horizons in Biblical Theology, 6:25-57.

KRUGER, M.A. 1993. 'n Weg uit die oorheersing van die histories-kritiese metode, fundamentalisme en genitiefteologieë. In die Skriflig, 27(4):583602.

MILL, J.S. 1996 [1869]. On liberty/The subjection of women. Hertfordshire: Wordsworth.

NOLL, K.L. 2001. The kaleideoscopic nature of divine personality in the Hebrew Bible. Biblical Interpretation, 9(1):1-24. 
PELLEGRINI, S. 2000. Elija - Wegbereiter des Gottessohnes: eine textsemiotische Untersuchung im Markusevangelium. Freiburg: Herder.

PIETERSE, R. 2002. Die "vroue-kwessie" in die GKSA. In die Skriflig, 36(4):691-716.

POSTMODERN BIBLE, see BIBLE AND CULTURE COLLECTIVE

RUTHVEN, M. 2004. Fundamentalism: the search for meaning. Oxford: Oxford University Press.

SELDEN, 1989. A reader's guide to contemporary literary theory. Lexington: University Press of Kentucky.

SNYMAN, G.F. 1991. Biblical hermeneutics and reception theory: the authority of biblical text and the chronicler's interpretation of the sacred story of the ark. (Unpublished D.Th dissertation; UNISA.)

SNYMAN, G.F. 1992a. Kenteoretiese besinning oor teologiebeoefening aan die Teologiese Skool van Potchefstroom die afgelope twintig jaar. In die Skriflig, 26(2):247-266.

SNYMAN, G.F. 1992b. Binnegevegte in die GKSA: verskuiwing van "plausibility structures". In die Skriflig, 26(3):351-367.

SPOELSTRA, B. 1989. Gereformeerde kerkreg en kerkregering: 'n handboek by die kerkorde. Hammanskraal: Teologiese Skool Hammanskraal.

THISELTON, A.C. 1992. New horizons in hermeneutics: the theory and practice of transforming biblical reading. Grand Rapids: Zondervan.

TRIBLE, P. 1982. Feminist hermeneutics and biblical studies. Christian Century, 99(4):116-119.

VAN DEVENTER, H.J.M. 1996. 'n Paradigma vir gereformeerde teologiese wetenskaps-beoefening - 'n voorstel. Koers, 61(4):441-456.

VERGEER, W. 1993. Teologie en kenteorie: 'n reaksie op die artikels van Gerrie Snyman. In die Skriflig, 27(4):563-582.

\section{Kernbegrippe:}

Gereformeerde Kerke in Suid-Afrika

sinodebesluite

vroue in die kerk

W. Iser en Bybelinterpretasie

\section{Key concepts:}

Reformed Churches in South Africa

synod decisions

W. Iser and Bible interpretation

women in the church 